Structural Adhesive Joints in Engineering 


\title{
Structural Adhesive Joints in Engineering
}

\author{
ROBERT D. ADAMS
}

BSc (Eng.) (Lond.), PhD(Cantab.), ACGI, C Eng., FIMechE, FInstP

Reader in Mechanical Engineering, University of Bristol, UK

and

\section{WILLIAM C. WAKE}

MSc, PhD, DSc(Lond.), FRSC, FPRI, Hon.DSc (The City University) Hon. Fellow, The City University, London, UK

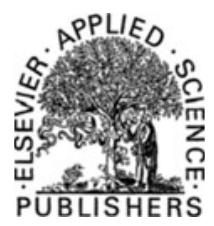

ELSEVIER APPLIED SCIENCE PUBLISHERS LONDON and NEW YORK 
ELSEVIER APPLIED SCIENCE PUBLISHERS LTD

Crown House, Linton Road, Barking, Essex IG11 8JU, England

Sole Distributor in the USA and Canada ELSEVIER SCIENCE PUBLISHING CO., INC. 52 Vanderbilt Avenue, New York, NY 10017, USA

\section{British Library Cataloguing in Publication Data}

Adams, R. D.

Structural adhesive joints in engineering.

1. Adhesive joints

I. Title II. Wake, William C.

624.1'89'9 TA492.A3

ISBN-13:978-94-010-8977-7 e-ISBN-13:978-94-009-5616-2

DOI: $10.1007 / 978-94-009-5616-2$

WITH 30 TABLES AND 125 ILLUSTRATIONS

(C) ELSEVIER APPLIED SCIENCE PUBLISHERS LTD 1984

Reprinted 1986

Softcover reprint of the hardcover 1st edition 1984

\section{Special regulations for readers in the USA}

This publication has been registered with the Copyright Clearance Center Inc. (CCC), Salem, Massachusetts. Information can be obtained from the $\mathrm{CCC}$ about conditions under which photocopies of parts of this publication may be made in the USA. All other copyright questions, including photocopying outside of the USA, should be referred to the publisher.

All rights reserved. No part of this publication may be reproduced, stored in a retrieval system, or transmitted in any form or by any means, electronic, mechanical, photocopying, recording, or otherwise, without the prior written permission of the publisher. 


\section{Preface}

The intention of this book is that it should contain everything an engineer needs to know to be able to design and produce adhesively bonded joints which are required to carry significant loads. The advantages and disadvantages of bonding are given, together with a sufficient understanding of the necessary mechanics and chemistry to enable the designer to make a sound engineering judgement in any particular case.

The stresses in joints are discussed extensively so that the engineer can get sufficient philosophy or feel for them, or can delve more deeply into the mathematics to obtain quantitative solutions even with elastoplastic behaviour. A critical description is given of standard methods of testing adhesives, both destructively and non-destructively. The essential chemistry of adhesives and the importance of surface preparation are described and guidance is given for adhesive selection by means of check lists. For many applications, there will not be a unique adhesive which alone is suitable, and factors such as cost, convenience, production considerations or familiarity may be decisive. A list of applications is given as examples.

The authors wish to increase the confidence of engineers using adhesive bonding in load-bearing applications by the information and experience presented. With increasing experience of adhesives engineering, design will become more elegant as well as more fitted to its products.

R. D. ADAMS

W. C. WAKE 


\section{Acknowledgements}

Acknowledgements are necessarily and gladly made by the authors for help, advice and criticism to Dr J. A. Harris of Bristol University, Dr A. J. Kinloch of the Ministry of Defence (PERME), Waltham Abbey, and Dr P. Poole of the Royal Aircraft Establishment, Farnborough. Former colleagues and students have contributed in the past to the work on which this book is largely based, in particular Drs N. A. Peppiatt, J. Coppendale and A. D. Crocombe.

The publisher joins with the authors in thanking those individuals and Journals listed below for permission to use diagrams and photographs which have either appeared elsewhere or are modifications of published material:

Adhäsion (Berlin) for Figs 99-101, 110 and 111 from papers by the late Prof. Dr-Ing. A. Matting.

K. W. Allen and J. Adhesion for Figs 107 and 108.

Dr W. Althof and Metall (Berlin) for Figs 116, 119 and 120.

Dr H. A. Burgman and J. Appl. Polym. Sci. for Fig. 118.

Dr J. Cotter and J. Adhesion for Fig. 115.

Prof. Dr-Ing. F. Eichhorn and Adhäsion for Fig. 114.

Engineering Sciences Data Unit Publication, ESDU 79016 for Fig. 33.

Dr L. J. Hart-Smith for Figs 32, 34-36 and the Douglas Aircraft Co., for Figs 37 and 38.

The Institution of Civil Engineers for Figs 54 and 56.

J. Adhesion for Figs 27-30, 69 and 87.

J. Strain Anal. for Figs 10, 13-23 and 63-68.

Dr H. Schonhorn and J. Appl. Polym. Sci. for Fig. 92.

Dr M. E. R. Shanahan and The City University for Fig. 98.

Dr B. Wargotz and J. Adhesion for Fig. 102.

Figures 1 and 124 are Crown Copyright and Fig. 109 is based on data supplied by the Royal Aircraft Establishment, Farnborough. 


\section{Contents}

Preface ..................

Acknowledgements ................ . vi

Chapter 1. INTRODUCTION . . . . . . . . . . . . 1

Joint Configurations: Lap-shear Joints, Butt Joints, Fillets. Metals and Other Constructional Materials. The Decision to Use Adhesive Bonding. The Balance of Advantages and Disadvantages

Chapter 2. THE NATURE AND MAGNITUDE OF STRESSES IN ADHESIVE JOINTS . . . · . Analysis. The Single Lap Joint: Linear Elastic Analysis, Volkersen's Analysis, The Analysis of Goland and Reissner, Effect of Bending in a Double-lap Joint, Volkersen's Second Theory, Later Work. The Single-lap Joint-End Effects: Reduction of Stress Concentrations. The Single-lap Joint-Elasto-plastic Analysis. The Effect of Adherend Shape-Scarfed, Bevelled and Stepped Adherends. Composite Materials. Tubular Joints. Butt Joints. The Use of Joints in Design: Lap Joints, Tubular Joints, T-joints, Corner Joints, Butt Joints, Stiffeners, Doublers, Assembly

Chapter 3. STANDARD MECHANICAL TEST PROCEDURES . . . . . . . . . . .

Destructive Testing: Tests with Thin Sheet Adherends, Tests for Properties of Adhesives. Nonvii 
destructive Testing: Nature of Defects, Tests Carried Out Before Bonding, Post-bonding and In-service Testing

\section{Chapter 4. THE GENERAL PROPERTIES OF} POLYMERIC ADHESIVES . . . . . . . .

Polymer Structures: Unsaturation. Mixed Adhesives. Properties and Temperature: The Glass Transition Temperature, Decomposition Temperature, Melting Temperature, The Deformation of Adhesive Polymers by Stress, Viscoelasticity, The Modulus of an Adhesive, Poisson's Ratio, Strength Properties of Adhesive Polymers, Yielding Stresses of Polymers, Failure Modes After Yielding, Creep, Failure without Yielding-Brittle Fracture, Crazing, Coefficient of Thermal Expansion, Resistance to Deterioration

\section{Chapter 5. FACTORS INFLUENCING THE CHOICE} OF ADHESIVE ...........

Interaction with Substrate. Structural Adhesives for Metals: Check-list for Structural Metal Adhesives Used at Temperatures up to $70^{\circ} \mathrm{C}$, The Advantage of Supported Filmic Adhesives ('Tapes'), Unsupported Films, Liquids and Pastes, Influence of Metal of Adherend, High Temperature Metal-Metal Adhesion. Structural Adhesives for Wood: Check-list for the Use of Structural Wood Adhesives. Structural Adhesives for Mixed Constructions: Metal-Wood Structures, Metal-reinforced Plastics Structures. Choice of Adhesives for Semi-structural Use: Checklist for Adhesives for Semi-structural Use

Chapter 6. SURFACE PREPARATION . . . . . .

Metals. Wood. Concrete. Glass or Carbon-fibre Reinforced Plastics. Shot, Sand or Grit Blasting. Solvent Degreasing or Wiping. Chemical Etching: Aluminium, Ferrous Metals, Titanium, Other Metals. Priming Layers: Primers as Coupling Agents

Chapter 7. SERVICE LIFE . . . . . . . . . .

The Creep of Adhesive Joints. Time-to-failure (Under Static Loading). Cycles-to-failure: Influence 
of Temperature, Influence of Test Frequency, Influence of Amplitude, Influence of Moisture. Effects of Temperature Change on Joint Strength. Service Life as Indicated by Climatic Exposure Trials

Chapter 8. APPLICATIONS

Aircraft, Anchorages. Bridges. Carriages. Cars. Decking. Furniture. Glass Reinforced Plastics. Helicopters. Helicopter Blades. Hovercraft. Lamp Posts. Magnets. PABST. Rollers. Segmental Construction. Ski Constructions. Telephone Kiosks. Yachts

References................. 283

Appendix: Standard American and UK Specifications for Adhesion Tests . . . . . . . . . . . . 293

Author Index . . . . . . . . . . . . . . . . . . . . . 299

Subject Index . . . . . . . . . . . . . . 303 